\author{
УДК 821.112.2 Rilke: 910.4(477:470+571) \\ https://doi.org/10.33989/2524-2490.2020.32.202445 \\ SVITLANA LEBEDENKO \\ ORCID 0000-0003-2865-9782 \\ (Полтава) (Poltava) \\ Place of work: Yaroslav Mudryi National Law University, Poltava Law Institute \\ Country: Ukraine \\ NATALIIA TARASOVA \\ ORCID 0000-0001-9712-9465 \\ (Полтава) (Poltava) \\ Place of work: Poltava V. G. Korolenko National Pedagogical University \\ Country: Ukraine \\ Email: taras0va@list.ru
}

\title{
“COUNTRY BORDERING WITH GOD": CHANGES IN RILKE'S AWARENESS UNDER THE INFLUENCE OF THE JOURNEYS TO UKRAINE
}

\begin{abstract}
У статті з'ясовано питання щодо впливу на свідомість видатного австрійського поета Райнера Марії Рільке східнослов'янського світу внаслідок подорожей, які він здійснив у 1899 і 1900 роках Росією та Украйною. Знайомство давньоруською культурою, з творами відомих украйнських $і$ російських письменників, поетів, художників, з украӥнською історією вплинуло на світосприйняття поета. Велике значення для Рільке мав «Кобзар» Тараса Шевченка. Враження, набуті під час подорожей Украйною, спричинили радикальний злам у творчості поета, змінили його світогляд.

Ключові слова: Рільке; філософія; світогляд; модернізм; Західна Европа; подорож по Росії та Україні; українська історія та культура; українська природа; Тарас Шевченко.
\end{abstract}

Formulation of the problem. The journeys to Russia and Ukraine, which Rainer Rilke made in 1899 and 1900, played a major role in his fate and greatly influenced the formation of his outlook. According to P. Ivanyshyn, "despite numerous attempts to study Rilke, he remains one of the most mysterious and "difficult to interpret" authors of the twentieth century" (Івашин). Not only because there are sometimes conflicting and ambiguous characteristics in evaluating the poet's work, but also because Rilke always tried to understand the reason for being. And events in his life, travels, observing the life of people greatly influenced the outlook, awareness of the poet.

In our opinion, travelling to Ukraine - Kyiv, Kaniv, Kremenchuk, Poltava, Kharkiv, nearby villages, meeting with famous poets, writers and artists, especially acquaintance with Ukrainian art, literature, architecture, had a special influence on the awareness of the famous Austrian poet.

Analysis of recent research and publications. Creative work by Rilke-modernist continues to interest literary critics. The scientific works by A. Berezina, P. Ivanyshyn, O. Izarskyi, L. Kravchenko, A. Neusykhin, Ye. Pelenskyi, K. Shakhova and others are devoted to his poetry, written under the influence of journeys to Ukraine. Internet resources, materials stored in local history museums and archives, texts by Rilke are also used in the article.

Emphasizing previously unresolved parts of a common problem. Despite a considerable amount of research on the creative work of Rilke, it is essential to systematize information about the influence on the creativity of the poet and changes in his awareness that occurred as a result of travelling to Russia and Ukraine.

The main purpose of the research is to find out how acquaintance with the culture of Kyivan Rus, with the history of Ukraine, with the creative works of famous Ukrainian artists influenced the awareness of the Austrian poet, "a poet of all-European scale and influence" (Державин, 2005, с. 441).

The main material. Based on our previous research on the journeys of Rainer Rilke to Russia and Ukraine, it should be noted that while travelling the Eastern Slavic world, the poet has met with many famous artists: prose writer L. Tolstoy, Russian poet with serfdom past S. Drozhzhin, artists L. Pasternak, A. Benois, I. Repin (met on May 18, 1899). 
He has seen the paintings of D. Levytskyi, M. Yaroshenko. Rilke was especially impressed with the works of artist V. Borovykovskyi. The poet studied the paintings of Ancient Russia and the sixteenth-eighteenth centuries, studied the relevant literature in the archives of Moscow, St. Petersburg. In Ukraine, the poet was very impressed with the works of Taras Shevchenko. He bought Kobzar in the Russian translation (Belousov's edition) and made extracts from many of his works. Rilke has kept Kobzar at his home library all his life. He was acquainted with M. Storozhenko, who studied the life and work of Taras Hryhorovych (Кузьменко, 2010, с. 198). The influence of T. Shevchenko's historical poems is evident in the work "The Truth Song". Rilke was interested in the figure of Taras Shevchenko so much that he even collected extracts about him from one French work. Unfortunately, they were not published and remain in the Rilke archive (Наливайко, 1971, c. 139). Thus, the personality of the great Kobzar, his creative work captivated the soul of a foreign non-Ukrainian poet. Rilke was able to appreciate T. Shevchenko's talent for his national character, truthfulness and simplicity.

There is some information about Rilke's interest in Mykola Gogol; the Austrian poet was especially impressed with the connection of Gogol's work with history and Ukrainian national tradition (Михальська, \& Щавурський (Ред.), 2006, с. 98).

Rainer Rilke was reading works about Ukraine, has translated into German The Tale of Igor's Campaign (1902 - 1904), published in 1930. The idea to make the translation came into being in Kyiv. It is known that in a letter to Sophia Schill on February 23, 1900, the poet wrote, "Among other books I was interested in The Tale of Igor's Campaign infinitely, Yaroslavna's crying is the best there" (Пеленський, 2003, с. 8). This translation remains the best of the German language to this day. Rilke has also translated works by M. Lermontov, L. Tolstoy, A. Chekhov, and F. Dostoevsky, discovering for himself the skill and depth of these Russian geniuses, Rilke sought to present their works to his countrymen.

It should be said that Rilke idealized Russia, a Russian man. He did not know the real Russia of the late nineteenth century, its acute problems, new ideas that were just emerging. But in our opinion, he did not want it. After all, he was interested and close to other Rus - not ordinary, problematic, but festive, ancient. This can explain why Rilke did not find a way to understand the work of A. Block, V. Bryusov, to the personality of M. Gorky. But the "Russian experience" that Rilke received, helped to feel confident in his ideas, to form the direction of further humanistic searches, convinced of moral criteria value for art (Березина, 1985, с. 112).

The journeys aroused interest in the history of Rus, Ukraine aroused a real sense of the scale of nature, grandeur and infinity. Rilke in Ukraine saw a world in which man has not yet been destroyed by the processes of alienation - the inevitable birth of a highly developed capitalist civilization. This was the reason why the poet was sympathetic to Russia and Ukraine, and accepted their national outlook as "the basis of his feeling and perception of the world" (Ніколенко, 2003, с. 88).

Ukrainian impressions caused a radical break in the poet's creative work, dramatically changed his outlook. It is Rilke among the poets of the early twentieth century who, with the greatest depth and power, expressed the tragedy of human existence in a world of dehumanization and alienation. Alienation, according to Rilke, is the distortion of the connection between people and the objects of their work. At the same time, no poet was so sad about the lost dignity of man, the world and people, the lost integrity and organic worldview (Наливайко, 1971, с. 147). In the Russians and Ukrainians, Rilke saw people who kept organic connections with nature, and this added faith:

Everything will be powerful and great again,

flat lands, high rivers,

big trees, small shadows

and the small valleys, where forever

farmers and shepherds will settle.

... Sincere hospitality reigns in homes,

a sense of self-sacrifice and trust

in you, in me, in everybody shines again (Бажан, 2004, с. 21). 
Interestingly, the journeys prompted Rilke to learn new languages. Before that he wrote poems in German and French. After the journeys he began to study Ukrainian and tried to write even in Russian. He was also called in Ukrainian: Rainer Yosypovych. And in the first years after the trips, the poet wore a beard and traditional Russian shirt with a red collar fastening at the side. He has kept Ukrainian souvenirs all his life: a silk shawl and a silver Byzantine cross (Марченко, 1998, с. 48). And the favourite dishes were borshch and porridge (Гармаш, 2000, с. 322). Warm memories about Ukraine are in unpublished letters to his mother (Пеленский, 2003, с. 8).

What attracted Rilke to Ukraine? What was he looking for here?

In the Ukrainian culture and literature poet sought something he lacked in Europe (Березина, 1985, с. 112). Rilke believed that God, lost by the Europeans, still lived here. And people are still in touch with him (Березина, 1985, с. 105). And without man, according to the researcher A. Neusykhin, God loses his importance (Неусыхин, 1977, с. 427). It was in Ukraine that the poet embraced a constellation consisting of "God", "people", and "nature". The Ukrainian people appeared before the poet as a "bearer of absolute values" (Кравченко, 2002, с. 49), inspired for self-improvement, and Ukraine "became his spiritual homeland", where "the poet found what he lacked in the atmosphere of the collapse of the Austro-Hungarian Empire - spirituality" (Кравченко, 2002, с. 52).

The journeys awakened a new perception and feeling of nature, which appeared before him in all its greatness and infinity, in its elemental originality. It is this nature that has awakened the poet's feeling of deep connection to the land. Now in his works, the images of the materially sensual world become the immediate object and purpose of poetry. The poet speaks of the confluence of nature and soul as a single stream of being, of an inseparable connection with the world and things. And this, in his opinion, is most important for the poet:

Those who saw him living, did not know

how much he was one with all this,

for, these valleys, these meadows,

and this water were his face (Бажан, 2004, с. 29).

According to the researchers, this poem reflected the impressions inspired by the visit to T. Shevchenko's grave, since a similar landscape can be traced from Chernecha Mountain.

R. Rilke, like many other writers, was often in the creative search. The formation of his outlook was influenced by various factors. German poet Rilke was born in Prague and was an Austro-Hungarian subject. He lived in an inter-ethnic atmosphere, and therefore in his early work the German-speaking tradition was often fused with Slavic and Hungarian influences. It was a great influence of French and Russian cultures on the poet. Such a synthesis, of course, enriched Rylke's lyrics and contributed to the fact that his creative work opened a new stage in the development of all European poetry.

On March 17, 1926, in a letter to an unidentified person, Rilke wrote: "You can easily imagine what a great impact my surroundings or the many countries have had on me; countries where, by the true mercy of my fate, I had the opportunity not only to stay as a traveler, but also to live there... Russia was decisive; it was in the years 1899 and 1900 that it opened to me an incomparable world, a world of unprecedented dimensions, and also because, because of the essence of the Russian people, I felt admitted to the human brotherhood... Russia became in full understanding the basis of my life perception and experience (you can be sure with The Book of Hours), as well as the unparalleled Paris became the starting point of my creative development after 1902" (Павлова).

In the early lyrics of Rilke, the influence of the fashionable moods of the end of the century is noticeable - loneliness, fatigue, longing for the past, which were mostly borrowed. He sought to distance himself from what he considered superfluous, vain, untrue, first of all - from the great modern industrial city, the inhuman bourgeois progress that goes along with the poverty and suffering of ordinary people. Over time, the poet learned to combine his self-absorption, sense of detachment from the world with the love of this world and peo- 
ple, because he perceived the love of people as an indispensable condition of true poetry. The impulse for this approach was the impression of two trips to Russia and Ukraine.

In his early work, Rilke was a neo-romantic and a symbolist, he depicted nature, dreams, love as cozy shelters of the soul; and in The Book of Hours, Rilke leaves symbolism and neo-romanticism, turns to philosophical knowledge of the world. It is the same "lust for the real", which has been expressed in the poet's further creative work. Travelling forced the poet to reconsider the style and manner of writing, the attitude to people. "Russia has become, in a sense, the basis of my experience and perception of the world", wrote the poet (Ніколенко, 2003, с. 88). It was his travels in Rus that completed the "educational years" and began a new phase in his work, as the main purpose of his life and art - "to bring harmony to the world" - was revealed (Ніколенко, 2003, с. 109). "True Rilke" begins with The Book of Hours and The Book of Images (Наливайко, 1971, с. 140).

We have already noted that Rilke has written many works under the influence of his travels. The poet not only received unforgettable impressions and conveyed them in poetry - his poetry was similar to Ukrainian poetry. Translator of the Rilke's Russian-language poems into German language Arthur Luther remarked: "It seems to me that a special melody of the Ukrainian language is extremely suitable for translation of the Rilke poem. You might think that Rilke himself could write in Ukrainian" (Кузьменко, 2010, c. 201). "This poet has created a lyrical language through which one can describe and feel the state of mind, spiritual problems and personal and religious experiences of a person",the German researcher Wilhelm Gosmann wrote such words about Rilke in "Essays on the History of German Culture" in 1966 (Ніколенко, 2003, с. 89).

Special mention should be made of Rilke's poetry translators. His works have been translated into Ukrainian by the best masters: P. Tychyna, M. Bazhan, V. Stus, D. Pavlychko, M. Lukash, L. Pervomaiskyi, M. Rudnytskyi, O. Zuievskyi, M. Zerov, Yu. Klen, M. Fishbein and others, M. Orest and B. Kravtsiv translated abroad. For Ukrainian readers, acquaintance with the work of Rainer Rilke began in the 60-70s of the last century. A selection of poetry in translations by L. Pervomaiskyi and V. Koptilov was published in the magazine Vsesvit (1968, No. 2); and in 1973 (in the same magazine) Rilke's poems appeared in M. Bazhan's translations. Then Vasyl Stus offered his translations to Vsesvit. However, the editorial board preferred Mykola Bazhan - a privileged poet, statesman. These and other translations made by M. Bazhan were published in 1973 in a separate book.

Mykola Bazhan became interested in Rilke's creative work at a young age. So when he started to translate, the work went surprisingly fast. But when Bazhan began to re-read his translations, he was dissatisfied, as he realized that he could not convey the ambiguity and versatility of Rilke's poems. But the magic of Rilke's word fascinated him and brought him back to work. On September 4, 1972, M. Bazhan wrote in a letter to a friend: "How I berate myself for taking up this difficult business. That's the goddamn Czech-Russian-Austrian-German magician and inventor! The teeth are sore, but at the same time it is addictive and won't let go. I obsess over it" (Бажан, 2004, c. 544). Like every joke, there is some truth here: Rilke's poetry is simple and at the same time complex and powerful. Everything as it should be in a true master, who felt involved in the deep sources of life, in the powerful origins of the natural creative forces of nature, so every word is well-balanced and hard-won, deep and the same time simple.

We agree with K. Shakhova's point of view that, while trying to find Rilke's place among the schools, currents, trends of the late nineteenth - early twentieth centuries, researchers of his work "attribute him to the symbolists, the neo-romantics, the impressionists or the expressionists. The truth is that living and creating in a turbulent (in terms of artistic search) time at the turn of the century, Rilke is a unique artist (Шахова, 2000, с. 98).

Conclusions and suggestions. Thus, Ukraine has played a decisive role in forming Rilke's poetic world, became his spiritual homeland, and the Ukrainian people was faced him as a "bearer of absolute values". In Ukraine and Russia, the poet found a desirable example of the spiritual unity of the people, their cohabitation with nature, in agreement with God, he did not see such things in Western Europe.

While in Ukraine, Rainer Rilke expanded his outlook, enriched himself spiritually, found the desired harmony. And under the influence of impressions, his outlook and attitude to life changed, he realized his purpose as a poet - to "bring harmony into the world" 
and love for people. Creative work brings new artistic expression techniques of thoughts and experiences, changing the style and manner of writing. R. Rilke's poetry, beginning with the Book of Hours and the Book of Images, opens a new stage in the development of European poetry.

\section{СПИСОК ВИКОРИСТАНИХ ДЖЕРЕ}

Бажан М. Вибрані твори. Київ : Вид-во ім. М. Бажана, 2004.

Березина А. Поэзия молодого Ридьке. Ленинград : ЛГУ, 1985. 183 с.

Гармаш Л. Ау Саломе. Челябинск : Урал, 2000. 341 с.

Державин В. Райнер Марія Рільке. Аітература й літературознавство. Вибрані теоретичні та літературно-критичні праці. Івано-Франківськ : Плай, 2005. С. 441-446.

Зарубіжні письменники : енциклопедичний довідник : у 2 т. / ред. : Н. Михальська, Б. Щавурський. Тернопіль : Навчальна книга - Богдан, 2006. Т. 2. 864 с.

Іванишин П. Поет і буття: специфіка онтологічного дискурсу Р.-M. Рільке. URL: http://dontsovnic.com.ua/poet-i-buttya-spetsyfika-ontolohichnoho-dyskursu-r-m-rilke/ (дата звернення: 15.12.2019).

Кравченко 1 . Визначна роль України у формуванні поетичного світу Райнера Марії Рільке. Рільке й Україна. Наукові студї та переклади Р. М. Рільке. Дрогобич : Дрогобицький держ. пед. ун-т імені Івана Франка, 2002. Т. 1. С. 48-53.

Кузьменко В. Історія зарубіжної літератури ХХ ст. : навч. посіб. Київ : Академія, 2010. 496 с.

Марченко Н. Рільке й Україна. Вікно в світ. 1998. № 3. С. 44-60.

Наливайко Д. Українські мотиви в поезї Рільке. Жовтень. 1971. № 10. С. 135-147.

Неусыхин А. Основные темы поэтического творчества Рильке. Райнер Мария Рильке. Новые стихотворения. Москва : Наука, 1977. С. 420-443.

Ніколенко О. Вивчення поезії XX ст. в школі: Гійом Аполлінер, Райнер Марія Рільке : посібник для вчителя. Харків : Ранок, 2003. 272 с.

Павлова О. Переклади творів Р. М. Рільке в архіві-музеї. URL: http://www.vsesvit-journal.com/old/content/view/316/41/ (дата звернення: 15.12.2019).

Пеленський Е. Рільке і Україна. Зарубіжна література. 2003. № 36. С. 8.

Шахова К. Райнер Марія Рільке - людина і поет. Зарубіжна література. 2000. Кн. 8. Ч. II (171). С. 6-9.

\section{SVITLANA LEBEDENKO NATALIIA TARASOVA}

“COUNTRY BORDERING WITH GOD": CHANGES IN RILKE'S AWARENESS UNDER THE INFLUENCE OF THE JOURNEYS TO UKRAINE

The article clarifies the problem of the East Slavic world influence on the awareness of the famous Austrian poet Rainer Maria Rilke as a result of the journeys he made in 1899 and 1900 around Russia and Ukraine. Acquaintance with ancient Russian culture, with works of famous Ukrainian and Russian writers, poets, artists, with Ukrainian history influenced the poet's outlook. Kobzar by Taras Shevchenko was very important for Rilke. The impressions gained during the travels around Ukraine caused a radical break in the poet's work and changed his outlook.

Was proved that, while trying to find Rilke's place among the schools, currents, trends of the late nineteenthearly twentieth centuries, researchers of his work "attribute him to the symbolists, the neo-romantics, the impressionists or the expressionists. The truth is that living and creating in a turbulent (in terms of artistic search) time at the turn of the century, Rilke is a unique artist.

Key words: Rilke; philosophy; outlook; modernism; Western Europe; travels around Russia and Ukraine; Ukrainian history and culture; Ukrainian nature; Taras Shevchenko.

\section{REFERENCES}

Bazhan, M. (2004). Vybrani tvory [Selected works]. Kyiv: Vyd-vo im. M. Bazhana [in Ukrainian]. Berezina, A. (1985). Poeziia molodoho Rilke [Poetry of the young Rilke]. Leningrad: LHU [in Russian].

Derzhavyn, V. (2005). Rainer Mariia Rilke [Rainer Maria Rilke]. Literatura i literaturoznavstvo. Vybrani teoretychni ta literaturno-krytychni pratsi [Literature and Literary Studies. Selected theoretical and literarycritical works] (pp. 441-446). Ivano-Frankivsk: Play [in Ukrainian].

Harmash, L. (2000). Lu Salome [Lou Andreas-Salome]. Chelyabynsk: Ural. P. [in Russian].

Ivanyshyn, P. Poet i buttya: spetsyfika ontolohichnoho dyskursu R.-M.Rilke [Poet and Being: The Specificity of the Ontological Discourse of R.-Rilke]. Retrieved from http://dontsov-nic.com.ua/poet-i-buttya-spetsyfika-ontolohichnoho-dyskursu-r-m-rilke/ (data zvernennya [accessed]: 15.12.2019) [in Ukrainian].

Kravchenko, L. (2002). Vyznachna rol Ukrainy u formuvanni poetychnoho svitu Rainera Mariii Rilke. Rilke i Ukraina [The prominent role of Ukraine in the formation of the poetic world of Rainer Maria Rilke. Rilke and Ukraine]. Naukovi studiii ta pereklady R. M. Rilke [Scientific Studies and Translations of R. Rilke] (Vol. 1, pp. 48-53). Drohobych: Drohobytskyi derzhavnyi pedahohichnyi universytet imeni Ivana Franka [in Ukrainian].

Kuzmenko, V. (2010). Istoriya zarubizhnoii literatury XX st. [History of foreign literature of the twentieth century]: navchalnyi posibnyk. Kyiv: Akademiia [in Ukrainian].

Marchenko, N. (1998). Rilke i Ukraina [Rilke and Ukraine]. Vikno $v$ svit [Window to the world], 3, 44-60 [in Ukrainian].

Mykhalska, N., \& Shchavurskyi, B. (Eds.) (2006). Zarubizhni pysmennyky [Foreign writers]: entsyklopedychnyi dovidnyk (Vol. 2). Ternopil: Navchalna knyha - Bohdan [in Ukrainian]. 
Nalyvaiko, D. (1971). Ukrainski motyvy v poeziii Rilke [Ukrainian Motives in Rilke's Poetry]. Zhovten [October], 10, 135147 [in Ukrainian].

Neusykhyn, A. (1977). Osnovnye temy poetycheskoho tvorchestva Rilke [The main topics of Rilke's poetry]. In Rainer Mariia Rilke, Novye stikhotvoreniia [New poems] (pp. 420-443). Moskva: Nauka [in Russian].

Nikolenko, O. (2003). Vyvchennia poeziyi XX st v shkoli: Hiyom Apolliner, Rainer Mariia Rilke [Studying the poetry of the twentieth century at school: Guillaume Apolliner, Rainer Maria Rilke]: posibnyk dlia vchytelia. Kharkiv: Ranok [in Ukrainian].

Pavlova, O. Pereklady tvoriv R. M. Rilke v arkhivi-muzeii [Translations of R. M. Rilke's works in the archive-museum]. Retrieved from http://www.vsesvit-journal.com/old/content/view/316/41/ (data zvernennia [accessed]: 15.12.2019) [in Ukrainian].

Pelenskyi, Ye. (2003). Rilke i Ukraina [Rilke and Ukraine]. Zarubizhna literatura [World Literature], 36, 8 [in Ukrainian].

Shakhova, K. (2000). Rainer Mariia Rilke - liudyna i poet [Rainer Maria Rilke - man and poet]. Zarubizhna literatura [World Literature], 8, II (171), 6-9 [in Ukrainian].

Отримано 03.12.2019 p. 